\title{
Strengthening Political Participation Through Education in Schools
}

\author{
Roy Kembar Habibi \\ Yogyakarta State University \\ Yogyakarta, Indonesia \\ rhabibi615@gmail.com \\ Eni Kusdarini \\ Yogyakarta State University \\ Yogyakarta, Indonesia \\ eny_kusdarini@uny.ac.id
}

\begin{abstract}
Political participation enforcement through education at schools played important roles and gave positive effects. By being given political participation enforcement, students as beginner voters would be able to have good political education and improve their knowledge of political participation in a social environment. Political participation education given by schools through civic education could provide experiences to students that had gained minimum understanding of the importance of political participation enforcement at a school environment. To form political education knowledge as an attempt to increase political participation at schools, students would understand the importance of political participation in order to realize democratic education and make them good citizens. This research was library research. Data in forms of article were collected from literary studies by analyzing political participation education implemented at schools. The research findings indicated that: 1) Political participation education enforcement at schools should have been given to develop students' knowledge on political education and 2) Students were able to be democratic citizens and improve political participation in a social environment.
\end{abstract}

Keywords- Political Education Enforcement, Political Participation, Political Education, Civic Education, Political Socialization

\section{INTRODUCTION}

The Law of the Republic of Indonesia Number 32 Year 2004 on Local Government commands the government to operate and manage their own domestic affairs or the implementation of local autonomy. In the Law, each region in Indonesia has their own duties and rights in managing their local government. Educational systems have also been regulated by the Law Number 20 Year 2003 on National Education System. Furthermore, the Law Number 20 Year 2003 clarifies that education is a conscious and planned attempt to realize a learning atmosphere and process that enable students to actively develop their potencies. National education is education based on Pancasila and the 1945 Constitution of the Republic of Indonesia. It lies on religious and cultural values of Indonesia and is responsive to the demand of world changes.

Education in Indonesia prepares students to be able to competitive citizens that can survive in either global education of education globalization changes. Hierarchally,
Indonesia is a modern state in terms of its education implementation. Modern state is the state that can form its citizens to be citizens that have good education in the education world. State with modern nationality is a state that has strong unity to upheld togetherness in the society. The 1945 Constitution of the Republic of Indonesia should be continuously generated to the young generation. Education is a manifestation of state concern to provide advanced knowledge for their citizens. To be a developed state, a certain state must improve education that actively advances a state, the modern nationality. Indonesia is a unity and republic state. The term of the Republic of Indonesia has been regulated in the 1945 Constitution. In its development, Indonesia has undergone rapidly developed changes, as in its education. Education in Indonesia can be categorized as the developed one through a good education concept to improve good knowledge that should be mastered by students. Furthermore, Indonesia embraces the democratic system that can only grow and develop if well sustained. By upholding democracy, citizens will not only gain their rights to live or individual rights, but also advance and improve the state as well as manage to achieve the state goals.

Education in Indonesia is expected to be able to prepare learners to be citizens with strong knowledge, commitment, and consistent to improve education quality. State with strong consistency and commitment on education will be an advance state that can improve education quality. Students are also expected to actively participate in learning activities in order to contribute to the education world. Schools are the most suitable place to provide good knowledge for students. Additionally, schools also develop advance mindset for students, improving education quality.

The above explanation engages in confirming that education at schools can improve education quality and good knowledge for students. In addition to that, schools can also teach students to be responsible in all consequences in their future. In the education world, teachers play an important role to give knowledge, as the nowadays, globalization has created a significant change in it. As educators or teachers, they should be able to socialize an important role and enforcement related to political participation to students at schools, especially for twelfth graders. Schools are one of the educational scopes provided for students, hence teachers, 
either civic education or other subject teachers, should be able to give socialization concerning political education for students. In this research, political participation enforcement given to students at schools are the roles of civic education teachers cooperating with other subject teachers to broaden knowledge of twelfth graders as beginner voters in political participationn education. Moreover, schools are a place to get special education that is impossible to get in a family environment. Besides, schools are also a good place to develop students' political view as beginner voters that will be implemented in the general election. As beginner voters, twelfth graders should be given education on active political participation as good citizens. In this research, beginner voters are those that are in the twelfth grade of senior high school, vocational high school, and Islamic senior high school. They need strategies to be good beginner voters given through civic education (Budiyanto, 1006:16).

In political education, political socialization should be given by teachers through civic education, for example, as in the subject, there are materials discussing politics. Enforcement on political education enables students to be more aware, actively participate, and give their votes in the future general election. Civic education teachers are expected to be able to give good knowledge related to active political participation to beginner voters, aiming to build their awareness and activeness in the political world. In formal education, political awareness establishment is conducted for the sake of good political awareness to improve students' political education as beginner voters. Not only teachers, extracurricular activities at schools can also provide students with knowledge, preparing them to participate in the general election. In those activities, students will gain developed and advanced related to political education. In school organizations, students or beginner voters are also suggested to join forums that develop their political education outside schools, because nationalism in politics should be developed in their spirit. Here, we should acknowledge that political participation education must be socialized to improve political awareness contained by values, norms, and habits of society for students that become beginner voters. Political life is a life that should be introduced to students in order to be implemented in the social life.

\section{LITERATURE REVIEW}

\section{A. Political Participation}

Political participation has become a variety owned by each state. The intended participation can also give political culture variety to either the society or students. Formerly, political participation was understood as political activities of the society, but today, political education or participation has embodied as education taught be teachers to their students. Political participation gives a broader variety for the society or students as beginner voters. Political participation is given to students to improve their education that can broaden their knowledge of political participation. Political participation will mediate political aspirations from the society and students. Political participation has a political socialization function for any existing political parties [1]

\subsection{Political Socialization}

Political education is a form of socialization given to citizens, providing them broad knowledge of political education. Political socialization given to students as beginner voters is also crucial to improve their political knowledge, education, and participation. Political socialization is expected to be able to give good and positive ambiance in improving students' knowledge to understand available political education [2]. Socialization is a long process for political education at schools. There are many social values socialized regarding political education at schools. Schools and learning play as political education agents that will give political knowledge and socialization to students. Political socialization given by teachers through education is based on their experiences that have become democratic citizens to improve political participation. By being given political education through political socialization at schools, students are expected to be able to active citizens willing to give their votes in the general election and improve their political awareness as beginner voters.

\section{B. Political Education at Schools}

Most political education at schools starts to be implemented and given through school learning. Education curricula should implement political participation education that has to taught at schools. By being given political education at schools, students can develop and broaden their political knowledge. Basically, political education is given to open students' political knowledge as beginner voters. Political participation and education given at schools are usually given through civic education that has a broad scope in social education, particularly in political education. Political education at schools becomes formal learning and education to give political knowledge for students. Political education at shools gives both positive and consistent effects to students as beginner voters in the social environment. Political education at schools are expected to be education for students, making them actively participate at schools, create better future, and understand the importance of polotical education to be implemented in the social environment [3]. Political education is very important for teenagers as students that are beginner voters in the future political world. Political education for teenagers should also be well improved to be able to provide good political knowledge, making them able to actively participate in the political education world. Political participation should be given through socialization at schools by either other subject teachers or civic education teachers that have broader material scopes and better knowledge. Schools play an important role in the process of political socialization for students, as schools are one of the institutions responsible for children education. Children experience changes in their political behaviors after entering schools and conducting communication and interaction with the school society, enabling them to gain experiences to solve both their personal and social problems. Schools play a crucial and fundamental role in the process of political socializatong given to students, i.e. helping their development to be social human beings, those that can well adapt to the society; making them become good citizens; and giving them understanding of 
their duties and rights as citizens. The process is importent since eventually, students will live among the society.

\section{METHODOLOGY}

Method applied in this research was the library research method with the inductive analysis model. The method was named as library research, because data or materials gained or required to complete this research were collected from libraries, i.e. books, encyclopaedia, dictionaries, journals, documents, and magazines [4]. By doing the inductive analysis, various themes, categories, and relationship patterns in those categories would appear. Library research was performed by employing sources from libraries to collect research data, implying that it restricted field research [5]. Library research was important in research, since research was unseparated from scientific literatures. This research was conducted by analyzing various writings related to political participation existing at schools given by teachers to students as beginner voters.

\section{RESULTS AND DISCUSSION}

\section{A. Political Participation Education}

Political participation given through education at schools constituted education that had better knowledge to form students' characters and knowledge [6]. Political education given to students aimed to improve students' education and knowledge to make them more active in the general election activity. Political participation education given to students were based on teachers' knowledge and experiences aimed to improve active roles of beginner voters in improving their political participation. Political activities would develop and grow students' mindset as beginnner voters, giving them knoweldge to choose their future leaders and making them aware that they had votes to be given for the state leader candidates. Beginner voters should have been given political education to improve their participation. All existing participations were the means enabling students to get directly involved in selecting the state leader candidates. Education and learning given to teachers build factors that could motivate students to participate and give their votes in the general election.

Political participation had by students would establish their mindset to create active participation knowledge and thus give their votes. Political participation education given by teachers was the school awareness to give political knowledge to students. Political education was also given through civic education with a broad scope of political world. Not only given through formal education, non-formal education could also give political participation education and knowledge about the importance of political participation to students. Political participation education could also be provided through organizational education outside schools, as extracurriculair organizations.

When political participation had been given, the education world would have different atmospheres. Political participation education was given to encourage advanced knowledge for students and develop their democratic spirit as citizens. Political participation education at schools was given no only by civic education teachers but also other subject teachers. Political participation education given by schools to students obliged teachers to actively and creatively provide political socialization through education from various learning sources. For example, was the Internet, one of the political participation education socialization media that could provide ample knowledge and was highly accessible for students, developing their democratic spirit and making them willing to accept political participation sources served by any available media [7]. Political participation education given by schools proved that political participation was indeed important to be given and taught. Political participation education at schools embodied a small political socialization form given by teachers to their students. By teaching political participation education, teacher would open students' knowledge about political participation that fortunately had been one of the state current learning materials.

Political participation education was given through various socialization methods to increase political education knowledge. Political education at schools was usually given through education taught by teachers. However, political participation education could not only given through learning materials, but also other forms of education; such as political education through the Internet. Political education through the Internet should have been properly delivered to school students, as the Internet could provide information about political education. The Internet was one of the communication media rapidly developed in this era. Information on political participation education provided by the Internet was highly diverse. Political participation education was aimed to increase political trust of students. By studying political participation education, students would understand the importance of political participation they sould have had.

In this current digital era, political education participation was so diverse in terms of political education delivery. Vast theories argued that once political education was given, it would develop curiosity and able to improve political participation that was imprinted in students. The Internet was an information source that provided knowledge on political participation for students, encouraging them to be active in politics. By the development of the Internet, students would receive much information on political education participation [8]. From the later perspective, the Internet was one of the communication media that were able to rapidly provide knowledge and education on political participation well and improve students' active roles, creating them to be active citizens while judging political issues. Furthermore, the Internet was also called information sources that could train students' knowledge to improve education related to the importance of participation given by either teachers on civic education subject or teachers on communication and information media. Another analysis confirmed that political education given to improve political participation was one of the posibble factors to improve political participation in either an educational or social environment. Political education given to improve political participation should have been able to improve students' political participation that later could be 
implemented in their social environment. Schools played a big role in the political knowledge improvement to encourage students to be active. Through education at schools, political education participation was always taught through learning materials or information education, i.e. teachers delivered learning materials to students through the Internet.

In political education, to improve participation, new concepts, methods, and models should have been given by teachers to students. As today, teachers had provided political education in forms of learning materials and learning materials from the Internet. To broaden students' knowledge, teachers should have generated knowledge and education innovations; such as through the internet education concept, a new education technology to improve political participation, as giving any available knowledge about politics. Through the Internet, teachers taught students to frequently read articles or news available on the Internet. By giving political participation education knowledge through the Internet, teachers asked students to actively comprehend political participation knowledge provided in the Internet. Because political participation developed and interacted in an individual environment, community, and society; environment also affected the improvement of political participation knowledge and education for students, causing them to implement it actively and well in their surrounding environment [9].

In terms of political participation education, teachers or educators play an important role in political education by creating innovation and creativity in while delivering political participation education knowledge. Knowledge given by teachers also played a crucial role for students to improve their political participation education. Additionally, civic education also played an important role in delivering political participation education and knowledge to students. Basically, civic education was a prominent education to explain political participation educatio to students. Civic education teachers should have been active and provide political participation knowledge and education for students at schools.

\section{B. Political Education at Schools}

Political education at schools was a form of political participation given by teachers at schools. As beginner voters, it was important for students to hold political education knowledge in their surroundings [10]. In political education given at schools, students were taught through civic education learning. Civic education presented learning materials that explained political education, education that was required to be implemented and taught to students as beginner voters. Political education given to students was the school encouragement to give knowledge aiming to improve students' awareness as beginner voters in the political world. By being given political participation education, students could be able to implement it in the social environment as democratic citizens. Democratic citizens were citizens that were open and able to express their opinions and give their votes in the general election. Democracy was education that was able to broaded students' knowledge in participating in political participation education development in their surroundings.

In giving political participation education, schools stimulated students to be active in political education. Political participation education given by schools could encourage students to improve their active participation. Schools could also improve students' active roles in increasing their political participation to be democratic citizens that were able to give their votes, express their opinions publicly, and accept all decisions and available political education [11]. Schools could provide not only direct political participation education by creating political education supporting their students to have political participation through formal education curricula, but also the indirect one that was through school climates, peer friends, and teachers that could create active participation in politics and encourage the students as beginner voters to create democratic civic education. There were several opinions explained that political participation given at schools would create and support students to be democratic citizens in the social environment. Political participation education given at schools would enable students to implement the education in the surrounding environment; hence they could have a broad view on political participation education.

Political education at schools was education through civic education. Civic education was formal education directly aiming to provide political participation education to students, making them democratic citizens. Civic education constituted one of the subjects preferred by students as beginner voters to improve their knowledge in the political world. Civic education subject taught students to be citizens that could participate in politics well and honestly. Impacts of political participation education given at schols became a political education control that had been implemented and taught to students. As one of the places where education was given, schools could also stimulate students' political participation well. By being given political education at schools, students would implement the education in the future general election. Impacts given to students related to political participation at schools would fulfill students' needs. There were three dimentions in political participation education given at schools through civic education, i.e. plitical tolerance, civic results, and volunteers. Those three dimentions provide chances for students to get political participation education they need, giving them effective functions as citizens with a good democratic spirit.

As a reference, teachers carried a positive value to improve students' active roles as beginner voters in political education. Teachers were also one of the sources that could explain and socialize students' political participation well. Political education at schools was also formal plotical education obtained by students at schools. Teachers acted as the means to achieve the curriculum target that had been stipulated by the previous decision makers by being based on standardized competences, basic competences, and indicators as the achievement measuring instruments. In general, teachers behaved as an organical intellectual in the 
bureaucracy and state society sections, hence, the acted as the media for the regime interests. However, given teachers acted as an agent, they would act as a curriculum developer and modifiy the curriculum based on available space and time. Civic education subject was the learning source of the importance of political participation education enforcement and improvement at schools.

Active roles had by civic education to improve political education at schools were by improving education curricula that later became new learning and education in the school environment. Students should have been provided knowledge on political education, since schools were the place and source of education that would improve students' knowledge related to political education at schools. Political education should be socialized to improve students' knowledge at schools. Schools were expected to be consistent in improving and giving political knowledge and education to students. Hawley conveyed that formal education was proper education to improve and develop political education for students at schools. Political education was taught at schools to improve students' democratic spirit in obtaining political education and knowledge that was later implemented in the society [12]. Schools could provide democratic values and political knowledge for their students. Political education given by schools would develop knowledge actively and able to increase students' interests and responsible as active citizens that could participate in politics.

Political education given by teachers at schools was political learning openly arranged and taught with various education alternatives. Political education curricula should have been developed in education to increase students' knowledge in politics. Teachers provided knowledge indoor to students and expected that later, the knowledge could be implemented in their social environment. School environment was a proper and conducive environment to improve political education, as schools were able to teach democratic education to their students. Schools were an environment that played a crucial role in the improvement of students' democracy to gain political education delivered by teachers or educators. The best method to improve and develop knowledge on political education to students was to improve their political skills and participation at schools [13]. Schools also had well democratic cultures that could improve students' political knowledge and education. Schools implemented political education curricula through civic education. In the class context, democratic education on political education was also implemented in the captain and class committe selection that later would improve students' learning activeness in political education.

Political education given by teachers at schools would position students and teachers in learning political education. Teachers deliver political education to be understood by students in social sciences. Civic education contained political education based on the teachers' experiences. Teachers asked students to discuss and solve political problems found around them. Next, teachers asked students to learn political education around them and discuss it in the class as an attempt to improve political knowledge and education. At schools, political education was pgiven interesting and creative learning materials, enabling them to actively participate and own broad knowledge on political education. Schools had different methods from the society's in giving political knowledge for students. In the social environment, students gained political education from the society's perspectives and experiences as well as political activeness and participation; while at schools, they got the education through sciences as learning materials in civic education. Besides, teachers' experiences and knowledge also broaden their political education at schools [14]. On the other words, political education given by schools to students was political education referring to educational curricula and teachers' knowledge. The education would improve political education for students in the school environment.

\section{CONCLUSION}

Political participation enforcement through education at schools was highly required to improve political education and participation awareness. Political participation education given by students at schools would give them broad knowledge on politics. Political education, participation, and socialization would make students as beginner voters become democratic citizens. Being democratic citizens meant being able to give votes in the general election. Both schools and teacher played an important role in giving political participation enforcement at schools, either through civic education and extracurriculair activities.

Political participation enforcement given at schools aimed to improve students' knowledge and make them actively think and participate in the general election. Enforcement at schools was given to students as beginner voters, preventing them to be confused of politics found in a social environment. By teachers' experiences given and taught to students, they would have understanding that political participation was the most important aspect to improve democratic education and be able to make them good citizens.

\section{REFERENCES}

[1] Suharti, B. 2014. Sosialisasi Politik dan Komunikasi Politik Anggota Dewan dalam Memberikan Pendidikan Politik dan Menjaring Aspirasi Masyarakat. Jurnal Sosiologi, Vol. 16, No. 2: 67-76.

[2] Reichert, F. \&Print, M. 2017. Civic participation of high school students: theeffect of civic learning in school. Educational Review, DOI: 10.1080/00131911.2017.1316239.

[3] Zed, M. 2008. Metode Penelitian Kepustakaan. Jakarta: PT Raja Grafindo Persada.

[4] Harahap, N. 2014. Penelitian Kepustakaan. Jurnal Iqra. 8(1), 68-74.

[5] Omelicheva, M. \&Ahmed, R. 2018. Religion and politics: examining the impact of faithon political participation. Religion, State, \& Society, 46:1, 4-25, DOI: 10.1080/09637494.2017.1363345.

[6] Stockemer, D.2012. Students' political engagement: a comprehensive study of University ofOttawa undergraduate students. Journal of Youth Studies, 15:8, 1028-1047, DOI: 10.1080/13676261.2012.693587.

[7] Wang, S,I. 2007. Political Use of the Internet, Political Attitudes, and Political Participation. Asian Journal of Communication, 17:4, 381395. http://dx.doi.org/10.1080/01292980701636993.

[8] Quintelier, E. 2008.The effect of schools on political participation: a multilevel logistic analysis. Research Papers in Education, 25:2, 137 154, DOI: 10.1080/02671520802524810. 
[9] Wojcieszak, M, Bimber, B, Feldman, L \& Jomini. 2015. Partisan News and Political Participation: Exploring Mediated Relationships. Journal Political Communication, DOI: 10.1080/10584609.2015.1051608.

[10] Robles, M,J , De Marco, S \&Antino, M. 2012. Activating Activists The Links Between Political Participation And Digital Political Participation. Communication \& Society, 16:6, 856-877, Doi: 10.1080/1369118x.2012.738238.

[11] Nugent, R. 2007. Civic, social and political education: active learning, participation and engagement. Irish Educational Studies Vol. 25, No. 2, June 2006, pp. 207_229. DOI: 10.1080/03323310600737552.
[12] D. Hawley. 1971. Political education and school organization. Theory Into Practice, 10:5, 328-335, DOI: 10.1080/00405847109542354.

[13] Harber, C. 2006. International Contexts for Political Education. Educational Review, 43:3, 245-255, DOI: $10.1080 / 0013191910430301$

[14] Snir, I. 2016. Re-politicizing the scholastic: school and schoolchildren between politicization and depoliticization. Ethics and Education, DOI: $10.1080 / 17449642.2016 .1160522$ 